\title{
ANALYSIS OF CYCLE 8 PERIOD FLYING STAR FENG SHUI ON CYCLE 7 PERIOD RESIDENTIAL SPACE LAYOUT
}

\author{
${ }^{1}$ Craven Arden Liman. ${ }^{2}$ Dr. Ir. Hartanto Budiyuwono, M.T. \\ 1 Student in the Bachelor's (S-1) Study Program in Architecture \\ at Parahyangan Catholic University \\ 2 Senior lecturer in the Bachelor's (S-1) Study Program in Architecture \\ at Parahyangan Catholic University
}

\begin{abstract}
Flying Star Feng Shui is one of many Feng Shui form using compass method. Flying Star Feng Shui uses Lo Shu Square with constantly changing number on each palaces for every periods, unlike traditional Lo Shu Square which has been used for thousands of years. The concept of Flying Star Feng Shui lies on dynamic principle of time which changes the luck of a person. The objects on this study is a few houses in Bandung City which is built in cycle 7 period (1984 - 2003).

The methods used to analyze this study is qualitative descriptive, which the writer observe each of the objects directly and analyze them using 2 reference books. David Twicken's Flying Star - Feng Shui Made Easy and Vincent Koh's Basic Science of Feng Shui.

In the end of this study, the conclusion is Flying Star Feng Shui surely can influence the life of the people living in the house. Some events in their life in cycle 8 can be foreseen by Flying Star Feng Shui, such as robbery, lawsuits, and illness.
\end{abstract}

Key Words: Flying Star Feng Shui, Houses, Events in the life of house users.

\section{ANALISIS FENG SHUI BINTANG TERBANG PERIODE 8 PADA PENATAAN RUANG RUMAH TINGGAL PERIODE 7}

\author{
${ }^{1}$ Craven Arden Liman. ${ }^{2}$ Dr. Ir. Hartanto Budiyuwono, M.T. \\ ${ }^{1}$ Mahasiswa S1 Program Studi Arsitektur Universitas Katolik Parahyangan \\ 2 Dosen Pembimbing S1 Program Studi Arsitektur Universitas Katolik Parahyangan
}

\begin{abstract}
Abstrak- Feng Shui Bintang Terbang merupakan salah satu cabang ilmu Feng Shui yang menggunakan metode kompas. Feng Shui Bintang Terbang menggunakan kotak Lo Shu yang memiliki angka - angka yang berubah untuk setiap periodenya, tidak seperti Lo Shu yang sudah digunakan sejak ribuan tahun yang lalu. Pemikiran Feng Shui Bintang Terbang didasarkan pada adanya perubahan waktu yang menyebabkan keberuntungan seseorang juga dapat berubah. Objek penelitian merupakan beberapa rumah tinggal di Kota Bandung yang selesai dibangun dan ditempati pada periode 7 .

Untuk menganalisis penelitian ini, metode yang digunakan adalah deskriptif kualitatif, yaitu melakukan pengamatan objek secara langsung dan dianalisis menggunakan acuan sumber literatur buku Flying Star - Feng Shui Made Easy karya David Twicken, Ph.D., L.Ac. dan Basic Science of Feng Shui karya Vincent Koh.

Pada akhir penelitian, dapat ditarik kesimpulan bahwa Feng Shui Bintang Terbang dapat mempengaruhi kehidupan dari penghuni rumah tersebut. Kejadian - kejadian dalam kehidupan penghuni rumah pada periode 8 dapat diramalkan oleh Feng Shui Bintang Terbang, seperti perampokan, tuntutan hukum, dan penyakit.
\end{abstract}

Kata Kunci: Feng Shui Bintang Terbang, Rumah Tinggal, Kejadian Hidup Penghuni Rumah

\footnotetext{
${ }^{1}$ Corresponding Author: craven.liman@gmail.com
} 


\section{PENDAHULUAN}

Arsitektur tidak terlepas dari penciptaan sebuah wadah bagi aktivitas manusia, baik sebagai tempat usaha, tempat rekreasi, tempat berkumpul, ataupun sebagai tempat tinggal. Dalam perancangan tempat-tempat ini, ada sebuah ilmu topografi kuno yang berasal dari Cina yang memercayai bagaimana manusia, surga (astronomi), dan bumi (geografi) dapat hidup secara harmonis untuk kemakmuran hidup manusia ${ }^{2}$. Ilmu topografi kuno yang disebut Feng Shui ini pada awalnya dibawa oleh para pedagang dari Cina yang datang ke Indonesia untuk berdagang. Setelah ratusan tahun menetap dan hidup di Indonesia, perlahan tapi pasti ajaran ini pun tersebar tidak hanya pada kalangan orang-orang keturunan Tionghoa namun hingga ke penduduk keturunan Indonesia asli juga mulai menerapkan pemikiran ini ${ }^{3}$.

Feng Shui Bintang Terbang merupakan salah satu bentuk Feng Shui yang alami dan dinamis. Bintang Terbang ini merupakan bentuk Feng Shui yang paling sering digunakan oleh konsultan-konsultan Feng Shui terkemuka di Asia. Layaknya sebuah alat Catscan atau MRI pada dunia kedokteran, Bintang Terbang dapat menampilkan pengaruh yang terlihat dan tidak terlihat yang mempengaruhi lingkungan kehidupan manusia. Bintang Terbang ini dapat melihat pengaruh terpendam yang tidak dapat ditampilkan oleh bentuk-bentuk Feng Shui lainnya. Feng Shui Bintang Terbang sendiri baru mulai digunakan pada tahun 1864 dan merupakan pengembangan dari $\mathrm{Pa} K u a$ Lo Shu yang sudah ribuan tahun digunakan ${ }^{6}$. Kemunculan Feng Shui Bintang Terbang karena anggapan bahwa Pa Kua Lo Shu sudah ribuan tahun digunakan dan pasti sudah kurang relevan karena tidak mungkin selama ribuan tahun ini tidak ada perubahan.

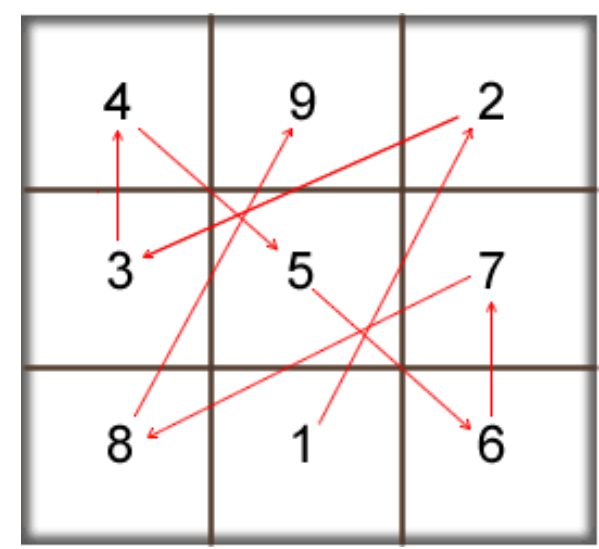

Figur 1.1. Diagram Lo Shu sebagai dasar Feng Shui Bintang Terbang

(Sumber : https://www.fscalc.com/)

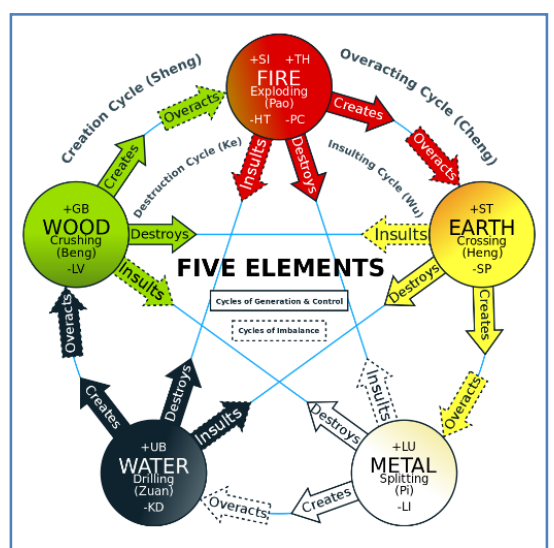

Figur 1.2. Siklus pada 5 Elemen yang menggambarkan kehidupan

(Sumber : 5elementsconstellations.com)

\section{KAJIAN TEORI}

Sepanjang sejarah kehidupan manusia, banyak hal-hal baru yang ditemukan untuk mencari makna terdalam dalam kehidupan manusia. Kesadaran bahwa Bumi merupakan sebuah benda langit yang berputar mengelilingi Matahari mengubah cara pandang manusia terhadap alam semesta. Berdasarkan penemuan inilah, manusia dapat menyadari bahwa alam semesta adalah sebuah kesatuan yang dinamis, selalu bergerak, dan selalu berubah. Feng Shui Bintang Terbang muncul atas dasar pemikiran bahwa semua kehidupan bergerak dan mengalami tahap-tahap tertentu yang dapat membawa kebaikan atau keburukan.

Efektivitas dan kekuatan dari Feng Shui Bintang Terbang berasal dari penggunaan waktu dan arah yang menciptakan energi pada sebuah bangunan. Arah bangunan merupakan sesuatu yang tetap dan tidak berubah, sementara waktu senantiasa mengalami perubahan. 
Setiap siklus yang baru akan membawa energi baru yang memengaruhi kesehatan, kemakmuran, keuangan, kasih, kreativitas, dan kemampuan manusia. Dalam Feng Shui Bintang Terbang, terdapat beberapa teori yang digunakan, diantaranya adalah 5 Elemen ( $W u$ Xing), kompas Lo Pan, Bintang Gunung (Mountain Star), dan Bintang Air (Water Star).

Dalam kehidupan manusia, ada sebuah energi $Q i(C h i)$ yang dapat mempengaruhi kehidupan manusia tersebut. Energi $Q i$ yang kurang baik dapat membuat manusia mengalami penderitaan seperti sakit, usaha tidak berkembang, maupun malapetaka lainnya yang tidak diinginkan terjadi dalam kehidupan. Untuk menganalisis aliran energi Qi ini, ada 2 hal yang harus diperhatikan, yaitu arah hadap rumah dan arah duduk rumah. Arah hadap rumah disimbolkan dengan air dan arah duduk rumah disimbolkan dengan gunung. Gunung dan air dalam Feng Shui tidak selalu harus dalam arti yang sebenarnya. Sebagai contoh, bangunan tinggi ataupun dinding tinggi dapat dianggap sebagai gunung, sementara jalan raya atau jalur sirkulasi utama dapat dianggap sebagai air. Kedua arah ini sangat penting dalam penerapan Feng Shui Bintang Terbang pada denah sebuah bangunan, karena dapat menentukan lokasilokasi strategis yang baik untuk peletakan ruang-ruang penting seperti kamar tidur maupun ruang makan ${ }^{8}$.

Beberapa orang yang menghuni rumah yang selesai dibangun pada periode 7 (Tahun 1984 - 2003) mengalami perubahan pada periode 8 (Tahun 2004 - 2023) karena adanya perubahan keberuntungan pada diagram Bintang Terbang. Tentunya permasalahan ini menjadi menarik untuk diteliti.

Berdasarkan latar belakang yang sudah dituliskan di atas, terdapat rumusan masalah yang menjadi fokus dalam penelitian ini yaitu bagaimana Feng Shui Bintang Terbang dapat mempengaruhi kehidupan penghuni rumah.

Penelitian tentang Feng Shui Bintang Terbang periode 8 terhadap penataan ruang dalam rumah tinggal periode 7 ini memiliki tujuan yaitu mengetahui pengaruh Feng Shui Bintang Terbang pada kehidupan penghuni rumah.

\section{METODA PENELITIAN}

Metode yang digunakan adalah metode kualitatif. Data-data diperoleh dari hasil wawancara langsung dengan penghuni pada objek penelitian. Denah rumah tinggal dan hasil wawancara digunakan sebagai sumber data utama dalam penelitian. Hasil wawancara sangat penting karena alasan pemilihan objek berdasarkan dari pengalaman hidup yang diceritakan penghuni melalui wawancara. Denah rumah tinggal digunakan untuk analisis Feng Shui Bintang Terbang terhadap penataan ruang sehingga bisa dilihat adanya bagian-bagian ruangan yang cenderung kurang baik.

Sumber data lainnya adalah tahun kelahiran masing-masing penghuni. Menurut teori pada sumber literatur ${ }^{1}$, tahun kelahiran merupakan salah satu yang penting untuk mencari elemen orang tersebut berdasarkan arah mata angin karena ada hubungan dengan 5 elemen pada teori Feng Shui Bintang Terbang.

Dasar teori yang digunakan pada penelitian ini adalah sebagai berikut :

\section{(1) Teori 5 Elemen (Wu Xing)}

Hubungan dari 5 elemen dalam Feng Shui yang dapat menciptakan pengaruh baik dan buruk pada bangunan. Cara untuk mengantisipasi energi ini adalah untuk mengurangi pengaruh buruk dan memperbanyak pengaruh baik. Untuk mengantisipasi pengaruh buruk yang ideal adalah dengan menambahkan elemen yang merupakan anak dari elemen yang dianggap berpengaruh buruk. Sebagai contoh, elemen air mengendalikan elemen api ${ }^{7}$. 
(2) Sembilan Bintang dalam Feng Shui

Dalam Feng Shui Bintang Terbang, ada 9 buah pengaruh khusus yang disebut "Bintang". Bintang dalam hal ini bukanlah bintang dalam arti sebenarnya, namun merupakan lambang dari pengaruh energi alam. Setiap bintang ini memiliki hubungan dengan angka, trigrams, warna, dan atribut dasar lainnya yang senantiasa berubah seiring dengan berubahnya waktu. Sifat alami dari sebuah bintang adalah keadaan ketika bintang tersebut berada pada kondisi netral. Penentuan kondisi netral atau tidaknya suatu bintang bergantung pada timeliness dari bintang tersebut ${ }^{4}$.

Timeliness pada Feng Shui Bintang Terbang terdiri dari beberapa tahap. Sebagai contoh, pada periode 7 (1984 - 2003), bintang 7 adalah Timely dan sangat menguntungkan. Bintang 8 adalah Future Timely atau bintang yang selanjutnya. Bintang 6 adalah Untimely. Bintang 7 sebenarnya merugikan, namun pada periode 7 dianggap menguntungkan karena angkanya sama dengan periode Bintang Terbang.

Pada periode 8, bintang 7 akan kembali menjadi Untimely dan sifat merugikannya akan kembali muncul. Inilah yang menjadi penyebab mengapa orang yang rumahnya selesai dibangun pada periode 7 mengalami hal kurang baik pada periode 8 , padahal sewaktu periode 7 tidak pernah ada masalah.

(3) Bintang Gunung dan Bintang Air

Dibagi menjadi dua aspek. Aspek yang pertama adalah kesehatan, hubungan, dan kesuburan yang dilambangkan dengan bintang gunung. Aspek yang kedua adalah keuangan, kekayaan, dan karir yang dilambangkan dengan bintang air. Dua (2) Aspek utama dalam hidup ini yang menjadi fokus utama Feng Shui ${ }^{1}$.

(4) Kombinasi Sembilan Bintang

Kombinasi Sembilan Bintang mewakili kombinasi khusus energi yang muncul di Alam Raya. Secara umum, Bintang Putih 1, 6, 8, Bintang Hijau 4, Bintang Merah 7, dan Bintang Ungu 9 dianggap sebagai bintang bagus. Bintang lain dianggap tidak bagus. Di antara mereka, Bintang Kuning 5 adalah yang paling berbahaya, diikuti oleh Bintang Hitam 2 dan Bintang Hijau $3^{9}$.

Selama Periode 7, bintang bagusnya adalah 7, 8, dan 9. Bintang 1 dan 4 kurang baik. Bintang 6 sudah lewat masa keberuntungannya. Bintang 2, 3, dan 5 merupakan bintang buruk. Sedangkan pada periode 8, bintang bagusnya adalah 8, 9, dan 1. Bintang 2, 3 , dan 5 masih merupakan bintang buruk, begitu juga dengan bintang 7 yang tidak lagi Timely sehingga kembali menjadi bintang buruk.

Pada tabel di bawah, terdapat kombinasi penting pada Bintang Terbang. Kombinasi ini dapat berupa Bintang Gunung dan Bintang Air, Bintang Gunung dan Bintang Tahunan, atau Bintang Air dan Bintang Tahunan. Faktor Timely adalah yang terpenting dalam studi Feng Shui Bintang Terbang. Bintang Kuning 5 yang tepat waktu dapat menjadi paling menguntungkan, sedangkan Bintang Putih atau Bintang Ungu yang tidak tepat waktu dapat membawa bencana.

Tabel 1.1. Kombinasi Penting Bintang Terbang

\begin{tabular}{|l|l|}
\hline $1: 4$ & Sukses dalam ujian, promosi, dan percintaan \\
\hline $1: 6,1: 7$ & Status, promosi, penghargaan, dan panjang umur \\
\hline $2: 3$ & $\begin{array}{l}\text { "Sha Banteng Mengamuk" } \\
\text { Pertengkaran, perselisihan, tuntutan hukum, penyakit perut }\end{array}$ \\
\hline $2: 5$ & Penyakit kirits dan kematian \\
\hline
\end{tabular}




\begin{tabular}{|l|l|}
\hline $3: 8,4: 8$ & Luka pada anak - anak \\
\hline $6: 7$ & $\begin{array}{l}\text { "Sha Pedang Bersilang" } \\
\text { Perkara hukum, tuntutan hukum, pertengkaran }\end{array}$ \\
\hline $7: 2$ & Dalam diagram Peta Sungai, kombinasi ini dapat membawa bahaya api \\
\hline $1: 8$ & $\begin{array}{l}\text { Meskipun bintang 1 dan bintang } 8 \text { berkonflik, ini tetap kombinasi yang baik, } \\
\text { membawa keunggulan akademis }\end{array}$ \\
\hline
\end{tabular}

(Sumber : Basic Science of Feng Shui, 2003)

\section{ANALISA}

\subsection{ANALISIS FENG SHUI BINTANG TERBANG}

Objek 1. Setelah menghitung angka trigram pribadi (Kua) dari setiap penghuni Objek 1 dari tanggal lahir masing-masing, didapatkan

Tabel 2.1. Elemen trigram pribadi (Kua) penghuni Objek Penelitian 1

\begin{tabular}{|c|c|c|}
\hline Anggota Keluarga & Angka Киа & Elemen Kua \\
\hline Suami & 3 & Kayu \\
\hline Istri & 7 & Logam \\
\hline Anak 1 & 1 & Air \\
\hline Anak 2 & 3 & Kayu \\
\hline
\end{tabular}

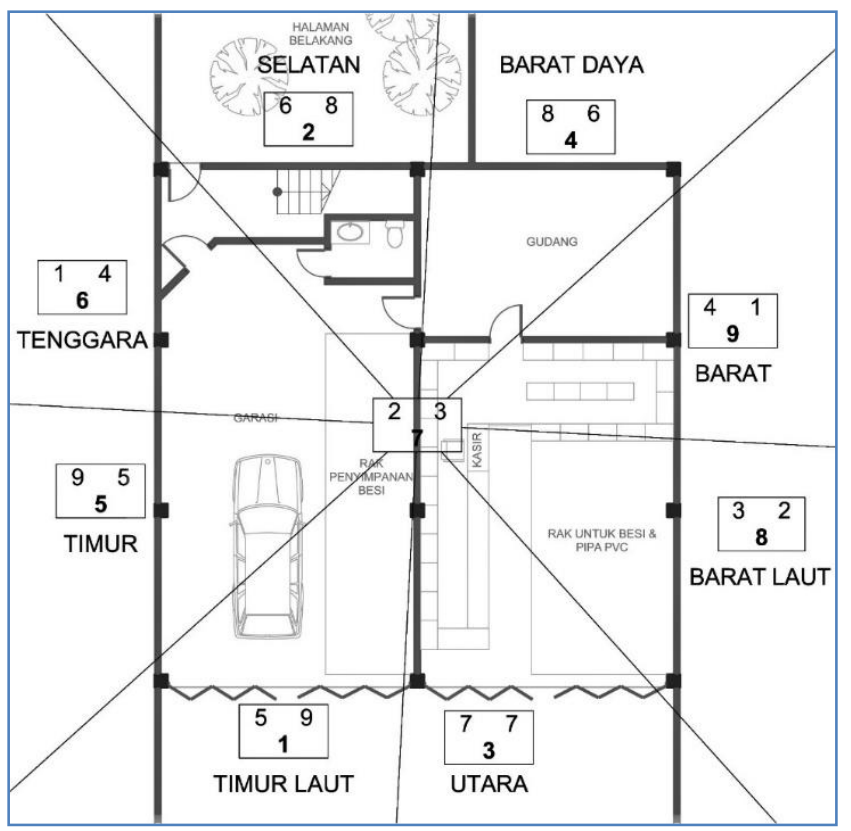

Figur 2.1. Pembagian letak ruangan lantai 1 berdasarkan Bintang Terbang

\section{$\underline{\text { Meja Kasir }}$}

Pada bagian toko yang penting adalah peletakan meja kasir dan pintu masuk utama karena inilah sumber datangnya uang sebagai penghasilan keluarga. Meja kasir dipengaruhi oleh kombinasi bintang 2 dan 3 yang merupakan kombinasi "Sha Banteng Mengamuk". Efek buruk dari kombinasi bintang 2 dan 3 pada periode 7 dapat diredam karena Bintang 7 merupakan Bintang Timely pada periode tersebut. Dapat dilihat dari omzet rata-rata penjualan toko setiap bulannya pada tahun 1993 - 1997 adalah Rp50.000.000,00 (berdasarkan hasil wawancara langsung dengan pemilik toko). Jumlah uang sebesar itu sangat bernilai sebelum krisis moneter melanda Indonesia. Sebagai contoh, harga jual sebuah mobil sedan jepang dalam 
kondisi baru hanya sekitar Rp40.000.000,00 - Rp60.000.000,00. Dapat dibandingkan dengan harga jual sebuah mobil sedan buatan Jepang yang sama dalam kondisi baru pada tahun 2017 sudah lebih dari Rp300.000.000,00. Pada periode 8, Bintang 7 untimely dan menjadi buruk sesuai dengan sifat asli dari bintang 7 (kurang beruntung) sehingga efek buruk dari kombinasi 2 dan 3 tidak dapat diredam lagi. Sejak tahun 1998, rata-rata omzet penjualan toko dalam 1 bulan berkurang jauh (angka penjualan secara Rupiah hampir sama, namun nilai tukar Rupiah terhadap mata uang asing melemah dan menyebabkan nilai Rupiah berkurang) bila dibandingkan dengan tahun 1993 - 1997. Jika sebelum krisis moneter harga jual sebuah mobil sedan buatan Jepang sekitar Rp40.000.000,00 - Rp60.000.000,00, harga jual mobil yang sama setelah krisis moneter melonjak naik menjadi Rp100.000.000,00 dan terus merangkak naik hingga sekarang. Pendapatan yang seharusnya kembali meningkat setelah krisis moneter juga tidak kunjung terjadi sehingga daya beli penghuni rumah menjadi lemah karena uang yang didapatkan tidak cukup untuk tabungan hidup seperti dahulu.

\section{$\underline{\text { Pintu Masuk Utama }}$}

Pintu masuk utama terletak di sektor Utara dengan kombinasi Bintang Gunung 7 dan Bintang Air 7. Pada periode 7, kombinasi Bintang Gunung 7 dan Bintang Air 7 ini membawa keberuntungan bagi toko. Dari hasil wawancara, keuntungan dari hasil penjualan dapat dikumpulkan untuk membeli properti, mobil, dan emas untuk tabungan pada waktu itu.

Pada periode 8, bintang 7 menjadi untimely yang memungkinkan terjadinya perampokan, kebakaran, atau kehilangan anggota keluarga. Sejak tahun 1998, rata-rata omzet penjualan toko dalam 1 bulan berkurang jauh (angka penjualan secara rupiah hampir sama, namun nilai tukar rupiah terhadap mata uang asing melemah dan menyebabkan nilai rupiah berkurang) bila dibandingkan dengan tahun 1993 - 1997. Pendapatan yang seharusnya kembali meningkat setelah krisis moneter melanda Indonesia tahun 1998 juga tidak kunjung terjadi. Efek buruk dari bintang 7 ganda di depan yang untimely juga berupa pengeluaran uang yang sangat besar sejak tahun 2007 (termasuk ke dalam periode 8) untuk keperluan pengobatan kanker yang diderita oleh istri. Walaupun jumlah uang yang dikeluarkan sudah mencapai satu miliar rupiah, pada akhirnya istri meninggal tahun 2009. 


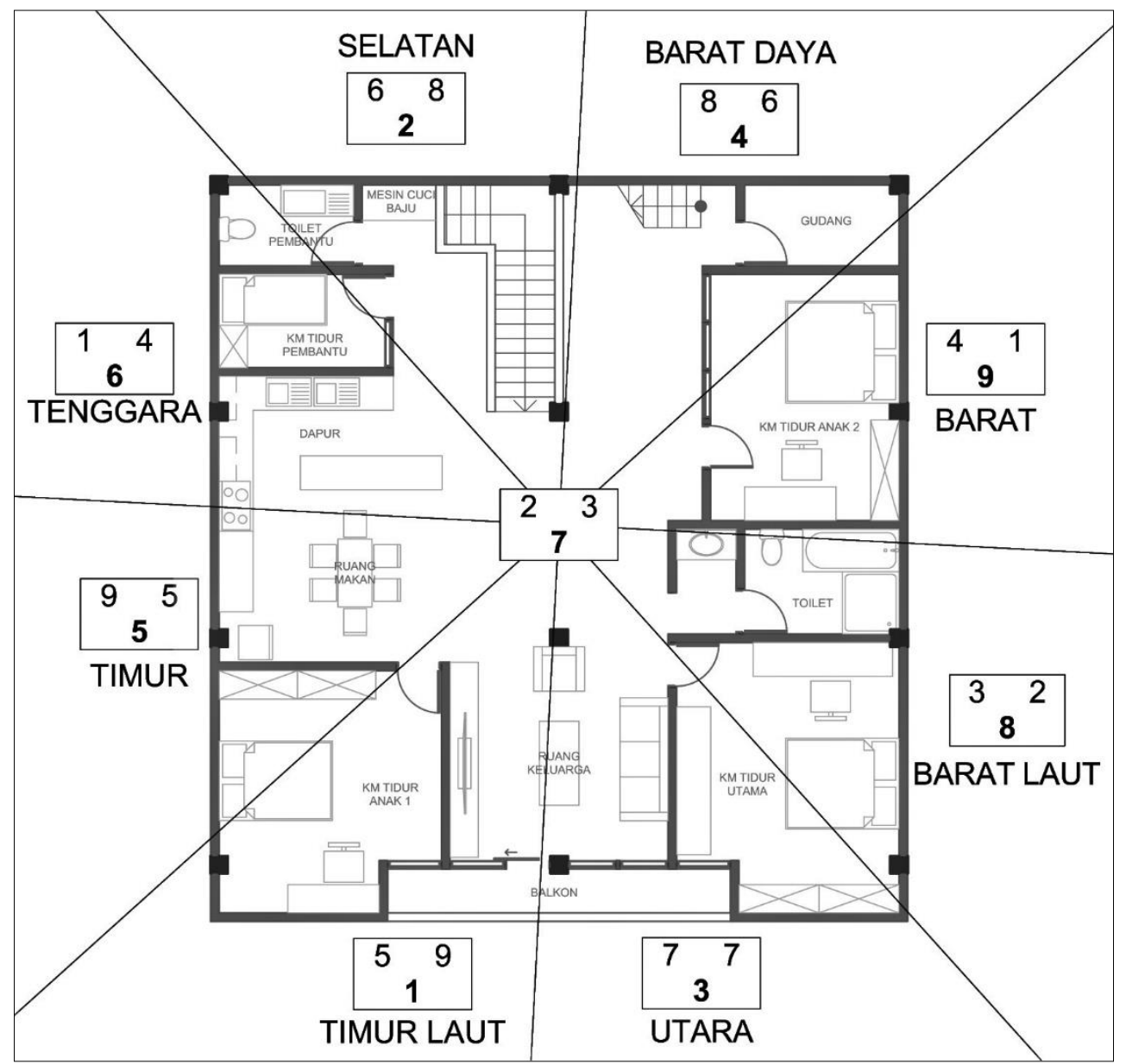

Figur 2.2. Pembagian letak ruangan lantai 2 berdasarkan Bintang Terbang

$\underline{\text { Kamar tidur utama }}$

Terletak pada sektor Utara dan Barat laut. Posisi kepala saat tidur terletak di sektor barat laut, dengan kombinasi Bintang Gunung 3 (kayu) dan Bintang Air 2 (tanah). Bintang 2 melambangkan Ibu. Jika dilihat dari hubungan 5 elemen, elemen kayu pada Bintang Gunung 3 mengendalikan elemen tanah pada Bintang Gunung 2 sehingga elemen tanah menjadi lemah, yang juga melambangkan Bintang "Ibu" dikendalikan oleh Bintang 3 sehingga kurang baik bagi Ibu.

Kombinasi Bintang 3 dan 2 ini merupakan kombinasi yang tidak baik dan akan membawa tuntutan hukum, pertengkaran, dan penyakit pada wanita tua di rumah. Kombinasi Bintang Gunung 3 dan Bintang Air 2 mungkin menyebabkan perempuan tua yang akan terluka atau meninggal ${ }^{1}$ sesuai dengan kenyataan yaitu istri (Ibu atau Perempuan tua di rumah ini) didiagnosa menderita kanker rahim pada tahun 2007 dan meninggal pada tahun 2009. Elemen Kua istri (7) yang merupakan logam juga berada pada siklus mengendalikan elemen kayu pada Bintang Gunung (3) sehingga kesehatan istri menjadi kurang baik. Bintang 2 juga melambangkan perut atas dan perut bawah yang sesuai dengan penyakit pada istri, yaitu rahim yang terletak di perut bawah.

Lain halnya dengan yang terjadi pada suami. Elemen Kua suami (3) yang berupa kayu sama dengan elemen bintang gunung (3, kayu) di sektor kamar tidur sehingga dalam bidang kesehatan cukup baik. Dari hasil wawancara juga tidak disebutkan bahwa suami pernah mengalami penyakit parah sejak tinggal di rumah ini. Dalam bidang keuangan, elemen Kua suami (3) yang berupa kayu berada pada siklus mengendalikan dengan elemen tanah pada bintang air (2) sehingga keuangan menjadi kurang baik. Bintang 7 ganda di pintu masuk tidak 
lagi dapat membantu keberuntungan, keuangan suami sebagai pemilik rumah dan toko terus menerus mengalami masalah, karena bintang 7 menjadi untimely di periode 8 . Selain dari toko yang tidak bisa berkembang, tabungan keluarga juga banyak terkuras untuk pengobatan penyakit kanker yang menyerang istri.

\section{$\underline{\text { Kamar tidur anak } 1}$}

Terletak pada sektor Timur dan Timur Laut. Sektor timur laut memiliki kombinasi Bintang Gunung 5 (tanah) dan Bintang Air 9 (api). Sektor timur memiliki kombinasi Bintang Gunung 9 (api) dan Bintang Air 5 (tanah). Posisi kepala pada saat tidur terletak di sektor timur. Kombinasi bintang 9 (api) dan 5 (tanah) akan menyebabkan bintang 5 menjadi lebih kuat. Hal ini disebabkan karena api memberi energi (siklus produktif) kepada tanah. Bintang 5 adalah bintang penyakit yang memiliki sifat buruk sehingga sifat buruknya malah diperkuat oleh kehadiran elemen api.

Elemen Kua anak sulung (1) adalah air yang berada pada siklus mengendalikan elemen api pada Bintang Gunung (9) sehingga kesehatan menjadi kurang baik. Dari hasil wawancara, anak sulung sudah menikah pada tahun 2009. Walaupun sudah 1 tahun menikah, anak sulung belum juga dikaruniai anak. Setelah memeriksakan diri ke dokter spesialis kandungan, ternyata anak sulung menderita Miom pada kandungannya. Diagnosa adanya miom ini pada tahun 2010 (termasuk dalam periode 8 ).

\section{Kamar tidur anak 2}

Terletak pada sektor Barat dan sebagian di Barat Daya. Posisi kepala berada di sektor barat yang memiliki kombinasi Bintang Gunung 4 (kayu) dan Bintang Air 1 (air). Pada periode 8, Bintang 1 menjadi distant future timely dan membawa keberuntungan bagi anak bungsu. Bintang Kombinasi bintang 4 dan 1 memungkinkan seseorang sukses dalam akademis atau percintaan ${ }^{1}$. Dapat dilihat dari anak kedua yang pada sempat beberapa kali berpacaran sebelum menikah (dari hasil wawancara) dan menikah pada usia yang lebih muda bila dibandingkan dengan kakaknya (anak bungsu menikah pada usia 23 tahun. Anak sulung menikah pada usia 26 tahun). Selain itu, anak bungsu merupakan lulusan S1 Desain Interior Universitas Kristen Maranatha dengan Indeks Prestasi Kumulatif yang tergolong tinggi (diatas 3.5). Unsur kayu pada elemen Kua anak bungsu (3) diperkuat oleh unsur air pada bintang air (1) dan unsur kayu pada bintang gunung (4), menyebabkan kesehatan dan keuangan anak bungsu menjadi baik.

Kesimpulan analisis objek penelitian 1 adalah perubahan periode bintang terbang secara umum membawa efek buruk pada rumah tinggal dan toko material karena berubahnya sifat timeliness (tepat waktu) dari bintang-bintang di sektor pintu masuk, meja kasir, kamar tidur utama, dan kamar tidur anak ke-1 (anak sulung). Namun, pada kamar tidur anak ke-2 (anak bungsu), perubahan periode bintang terbang ini malah memberikan pengaruh baik, karena kombinasi bintang gunung dan bintang airnya dapat membawa keberuntungan. Be gitu juga dengan elemen Kua anak bungsu yang tidak bertentangan dengan bintang gunung maupun bintang air di sektor kamar tersebut, yang menyebabkan kesehatan dan keuangan terdukung.

Objek 2. Setelah menghitung angka trigram pribadi ( $\mathrm{Kua}$ ) dari setiap penghuni Objek 2 dari tanggal lahir masing-masing, didapatkan

Tabel 2.2. Elemen trigram pribadi (Kua) penghuni Objek Penelitian 2

\begin{tabular}{|c|c|c|}
\hline Anggota Keluarga & Angka Kua & Elemen Kua \\
\hline Suami & 9 & Api \\
\hline Istri & 1 & Air \\
\hline
\end{tabular}




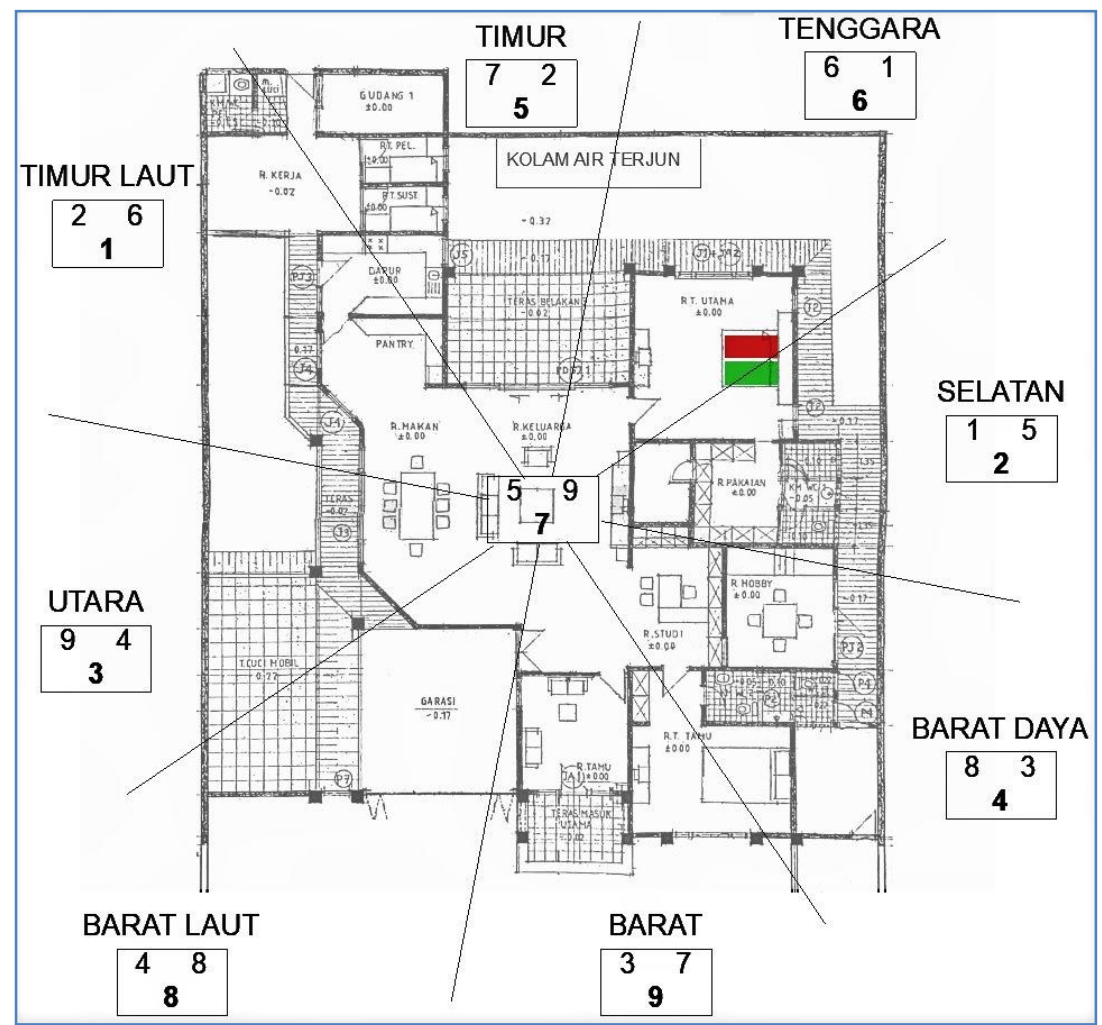

Figur 2.3. Pembagian letak ruangan berdasarkan Bintang Terbang

\section{Pintu Masuk Utama}

Pintu masuk utama rumah terletak pada sektor Barat yang memiliki kombinasi Bintang Gunung 3 (kayu) dan Bintang Air 7 (logam). Bintang Logam (7) mengendalikan Bintang kayu (3) pada siklus hubungan saling mengendalikan antar lima elemen. Bintang 3 merupakan bintang perampokan yang memiliki sifat asli kurang baik. Pada periode 7, kombinasi bintang 3 dan 7 dapat membawa perkembangan kekayaan ${ }^{1}$. Dapat dilihat dari nilai rata-rata omzet penjualan kain dari perusahaan tekstil milik suami setiap bulannya mencapai Rp1.500.000.000,00 (berdasarkan hasil wawancara langsung dengan Beliau). Pada periode 8, bintang 7 menjadi untimely dan kombinasi 3 dan 7 malah memperbesar kemungkinan terjadinya perampokan ${ }^{1}$. Dapat dilihat dari peristiwa perampokan tahun 2013. Sekitar pukul 05.00 WIB, seorang perampok masuk dengan memanjat pagar depan lalu membongkar teralis jendela kamar tamu. Perampok sempat masuk sampai ruang tengah dan membongkar laci-laci lalu segera keluar lagi melalui jendela yang dibongkar. Pada saat peristiwa perampokan terjadi, pasangan suami istri masih tertidur. Saksi dari peristiwa perampokan ini adalah pembantu yang hendak menyapu lantai. Mungkin karena melihat lampu dapur menyala, perampok tersebut segera melarikan diri sehingga tidak sempat melakukan aksinya lebih lanjut. Tidak diketahui dengan jelas wajah perampoknya karena ruangan yang gelap sehingga hanya terlihat bayangan manusia dari jendela dapur.

\section{Kamar Tidur Utama}

Terletak pada sektor Tenggara dan Selatan. Posisi suami saat tidur terletak di sektor selatan (warna arsir hijau), dengan kombinasi bintang 1 dan 5. Bintang Gunung 1 memiliki elemen Air, sedangkan bintang Air 5 memiliki elemen tanah. Elemen Tanah pada bintang Air mengendalikan Elemen Air pada Bintang Gunung yang berakibat kesehatan kurang baik.

Kombinasi Bintang 1 dan Bintang 5 dapat menyebabkan gangguan pada kandung kemih, karena Bintang 5 adalah Bintang Penyakit dan Bintang 1 berkaitan dengan ginjal. 
Gangguan ginjal ini terjadi pada suami yang sejak tahun 2006 sering mengalami masalah pada ginjalnya. Keluhan pertama kali adalah sulitnya buang air kecil, padahal dalam sehari sudah meminum air lebih dari 3 liter. Akibatnya, suami mengalami pembengkakan pada betis kakinya karena penumpukan air yang tidak dapat terbuang keluar. Suami sudah berobat hingga ke Singapura dan didiagnosis ada gangguan pada ginjalnya. Setelah pengobatan, buang air kecilnya menjadi normal kembali. Sayangnya 3 bulan setelah obat habis, gangguan ginjalnya kambuh kembali. Hingga saat ini masalah pada ginjalnya belum sembuh total karena selalu kambuh kembali. Elemen Kua suami (9) yang merupakan api juga dikendalikan oleh elemen air pada Bintang Gunung 1 sehingga kesehatan suami kurang baik.

Untuk istri, tidak ada permasalahan pada kesehatan dan keuangan karena posisi tidurnya berada di sektor tenggara dengan kombinasi bintang gunung 6 (logam) dan bintang air 1 (air). Elemen logam pada bintang gunung 6 dan elemen air pada bintang air 1 saling mendukung. Elemen Kua istri (1) berupa air mendapatkan dukungan baik dari bintang gunung 6 maupun bintang air 1 sehingga baik kesehatan maupun keuangannya tidak mengalami gangguan.

\section{$\underline{\text { Kolam Air Terjun }}$}

Terletak pada sektor Timur yang memiliki kombinasi Bintang Gunung 7 (logam) dan Bintang Air 2 (tanah). Bintang Air 2 merupakan bintang yang memiliki sifat asli kurang baik. Adanya air terjun pada sektor Timur ini mengaktifkan Bintang Air 2 sehingga efek buruknya bertambah kuat. Pada periode 7, efek buruk dari Bintang 2 tidak terlihat, karena dapat diredam oleh Bintang Gunung 7 yang timely. Ketika memasuki periode 8, Bintang Gunung 7 menjadi untimely sehingga tidak dapat meredam efek buruk dari Bintang Air 2. Dapat dilihat dari munculnya permasalahan pada perut yang menyerang suami sejak tahun 2006 (termasuk dalam periode 8$)$.

Kesimpulan dari analisis objek penelitian 2 adalah perubahan periode Bintang Terbang membawa pengaruh buruk pada kehidupan penghuni rumah karena berubahnya sifat timeliness (tepat waktu) pada bintang 7 di sektor pintu masuk dan kolam air terjun. Pada periode 8, bintang 7 menjadi untimely yang memunculkan sifat buruknya. Kombinasi bintang gunung dan bintang air yang kurang baik pada sektor kamar tidur, ditambah elemen Kua suami yang bertentangan dengan elemen pada bintang gunung memungkinkan kesehatan suami menjadi kurang baik.

Objek 3. Setelah menghitung angka trigram pribadi (Kua) dari setiap penghuni Objek 3 dari tanggal lahir masing-masing, didapatkan.

Tabel 2.3. Elemen trigram pribadi (Kua) penghuni Objek Penelitian 3

\begin{tabular}{|c|c|c|}
\hline Anggota Keluarga & Angka Киa & Elemen Кua \\
\hline Suami & 9 & Api \\
\hline Istri & 2 & Tanah \\
\hline Anak 1 & 9 & Api \\
\hline Anak 2 & 1 & Air \\
\hline
\end{tabular}




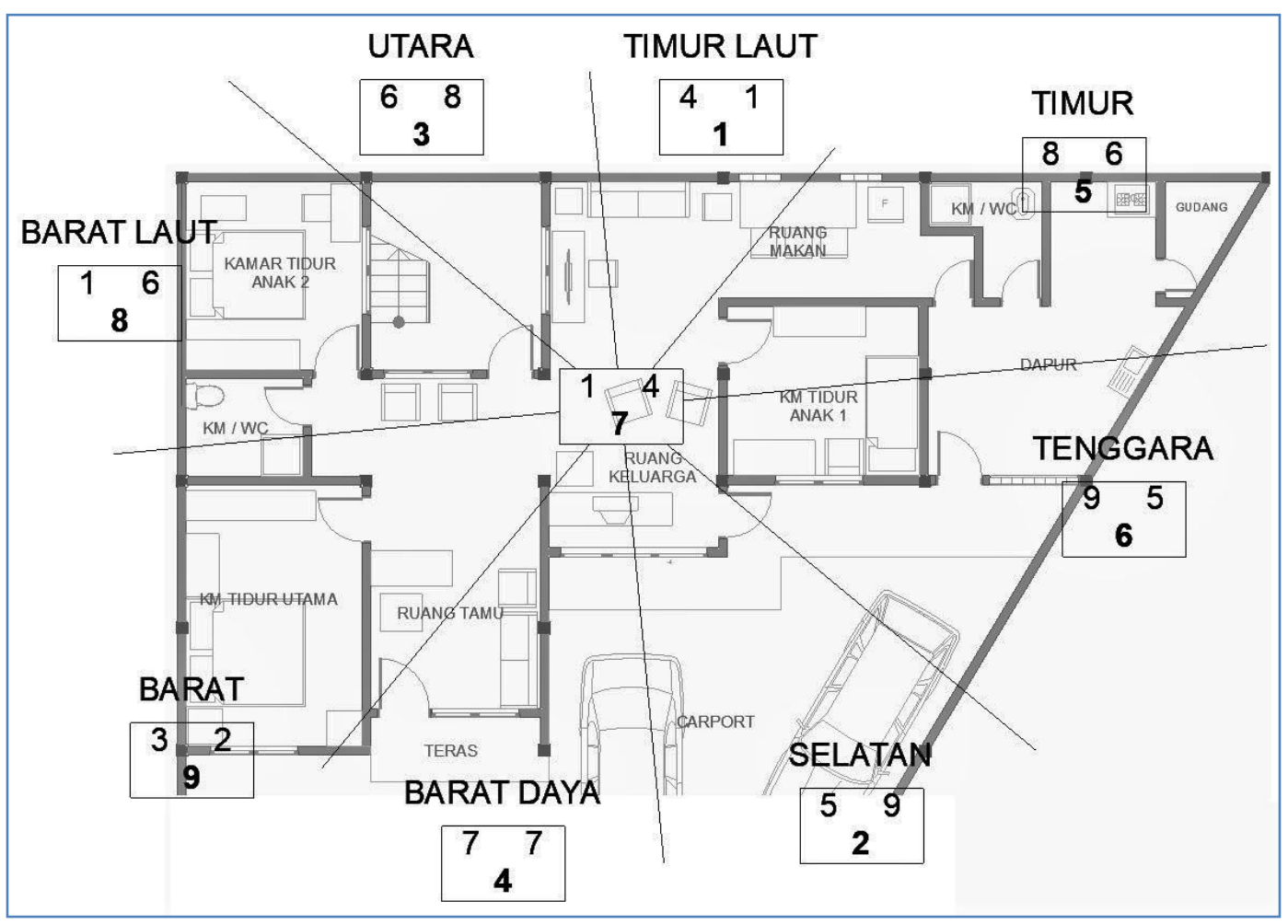

Figur 2.4. Pembagian letak ruangan berdasarkan Bintang Terbang

\section{Pintu Masuk Utama}

Pintu masuk utama terletak pada sektor Barat yang memiliki kombinasi Bintang Gunung 7 (logam) dan Bintang Air 7 (logam). Pada periode 7, kombinasi Bintang Gunung 7 dan Bintang Air 7 ini membawa keberuntungan yang besar bagi penghuni rumah, karena kedua bintang bersifat timely. Dapat dilihat dari jumlah rata-rata pendapatan bersih suami per bulan sebagai sales salah satu merk cat bangunan yang cukup besar sebelum periode 8 . Suami mulai bekerja di perusahaan tersebut pada tahun 1985 (termasuk periode 7). Ketika itu, sales mendapatkan gaji bulanan tetap dari pimpinan perusahaan, ditambah dengan bonus $30 \%$ yang dihitung dari berapa banyak cat yang dapat dijual kepada konsumen. Sistem perhitungan gaji dan bonus ini sangat menguntungkan pasangan suami dan istri ini. Mereka dapat menabung hingga memiliki toko material milik sendiri di Jalan Kopo Katapang.

Pada periode 8, bintang 7 menjadi untimely yang bersifat buruk. Dapat dilihat dari pendapatan suami yang berkurang jauh setelah tahun 2005 akibat adanya perubahan sistem perhitungan gaji dan bonus bagi sales di perusahaan tersebut. Sejak tahun 2005 (yang termasuk periode 8), sales tidak lagi menerima gaji tetap dari perusahaan, karena dianggap sebagai freelance. Selain itu, persentase bonus dari hasil penjualan cat juga mengecil (15\% dari total penjualan sales yang bersangkutan). Kebijakan ini muncul setelah perusahaan dipimpin oleh kepala wilayah yang baru. Karena suami merasa usianya sudah terlalu tua untuk melamar pekerjaan ke tempat lain (pada tahun 2005 suami berusia 41 tahun), suami memutuskan untuk tetap bekerja di perusahaan itu walaupun pendapatannya mengecil.

\section{$\underline{\text { Kamar Tidur Utama }}$}

Terletak pada sektor Barat dengan kombinasi Bintang Gunung 3 (kayu) dan Bintang Air 2 (tanah). Elemen kayu pada Bintang Gunung 3 mengendalikan elemen tanah pada Bintang Air 2 sehingga elemen tanah menjadi lemah. Kombinasi Bintang 3 dan 2 ini tidak baik dan dapat membawa tuntutan hukum, pertengkaran, dan penyakit pada wanita tua di rumah ${ }^{1}$. 
Bintang 2 memiliki trigram yang melambangkan Ibu. Karena Bintang 2 yang melambangkan "Ibu" dikendalikan oleh Bintang Gunung 3, maka kesehatan istri menjadi kurang baik. Sesuai dengan kenyataan yaitu istri (perempuan tua) terus menerus menderita sakit punggung sejak tahun 2007 hingga saat ini dan harus fisioterapi seminggu sekali. Elemen Kua istri (2) yang merupakan tanah juga dikendalikan oleh Bintang Gunung 3 yang berelemen kayu sehingga kesehatan istri menjadi kurang baik.

Untuk suami, angka Киа adalah 9 yang berelemen api. Elemen pada Киa suami tidak dalam siklus mengendalikan jika dilihat hubungannya dengan Bintang Gunung maupun Bintang Air. Bintang Gunung 3 (kayu) mendukung elemen api pada Kua suami (9), sementara itu elemen api pada Kua (9) mendukung Bintang Air 2 yang berelemen tanah.

Kesimpulan dari analisis objek penelitian 3 adalah perubahan periode Bintang Terbang membawa pengaruh buruk pada kehidupan penghuni rumah karena berubahnya sifat timeliness (tepat waktu) pada bintang 7 di sektor pintu masuk. Pada periode 8, bintang 7 menjadi untimely yang memunculkan sifat buruknya. Kombinasi bintang gunung dan bintang air yang kurang baik pada sektor kamar tidur juga memberikan pengaruh buruk kepada penghuni rumah, terutama istri yang menderita sakit punggung sejak 2007 dan harus fisioterapi, padahal sebelumnya tidak pernah sakit punggung seperti itu.

Objek 4. Setelah menghitung angka trigram pribadi (Kua) dari setiap penghuni Objek 4 dari tanggal lahir masing-masing, didapatkan.

Tabel 2.4. Elemen trigram pribadi (Kua) penghuni Objek Penelitian 4

\begin{tabular}{|c|c|c|}
\hline Anggota Keluarga & Angka Киа & Elemen Kua \\
\hline Suami & 2 & Tanah \\
\hline Istri & 8 & Tanah \\
\hline Anak 1 & 6 & Logam \\
\hline Anak 2 & 2 & Tanah \\
\hline
\end{tabular}

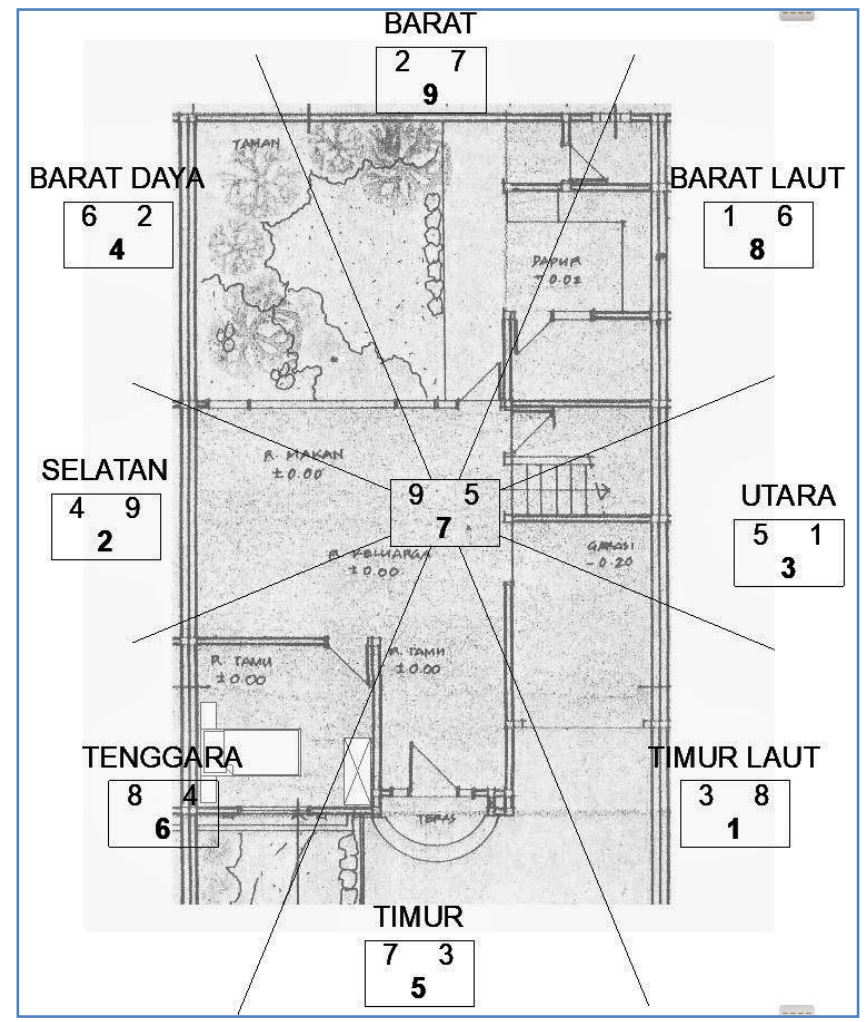


Figur 2.5. Pembagian letak ruangan lantai 1 berdasarkan Bintang Terbang

\section{Pintu Masuk Utama}

Pintu masuk utama terletak pada sektor Timur yang memiliki kombinasi Bintang Gunung 7 (logam) dan Bintang Air 3 (kayu). Elemen logam pada bintang gunung mengendalikan elemen kayu pada bintang air berdasarkan siklus hubungan saling mengendalikan antar lima elemen. Bintang 3 merupakan bintang perampokan yang memiliki sifat asli kurang baik. Pada periode 7, kombinasi bintang 3 dan 7 dapat membawa perkembangan kekayaan ${ }^{1}$ karena bintang 7 bersifat timely. Dari hasil wawancara, pendapatan rata-rata yang diperoleh suami tidak begitu berbeda dari tahun 1996 sampai sekarang. Pada periode 8, bintang 7 (logam) menjadi untimely dan memperbesar kemungkinan terjadinya perampokan atau terlibat dalam perkara hukum ${ }^{1}$. Dapat dilihat dari permasalahan hukum yang dialami oleh suami. Beliau bekerja sebagai agent asuransi kesehatan salah satu perusahaan ternama. Pada tahun 2008, beliau mengalami permasalahan hukum yang cukup rumit dengan kliennya hingga ke pengadilan. Malang bagi beliau, karena pengacara klien berhasil memenangkan tuntutan di pengadilan sehingga beliau sebagai tergugat harus membayar uang ganti rugi yang cukup besar. Untuk membayar uang ganti rugi tersebut, tabungan keluarga banyak yang terkuras, bahkan barang-barang milik pribadi terpaksa dijual karena uang tabungan keluarga masih belum cukup untuk membayar uang ganti rugi tersebut. Setelah tabungan keluarga terkuras, keuangan keluarga ini sulit sekali bangkit karena banyaknya kebutuhan lain yang harus dipenuhi. Akhirnya keluarga ini terpaksa hidup secara pas-pasan.

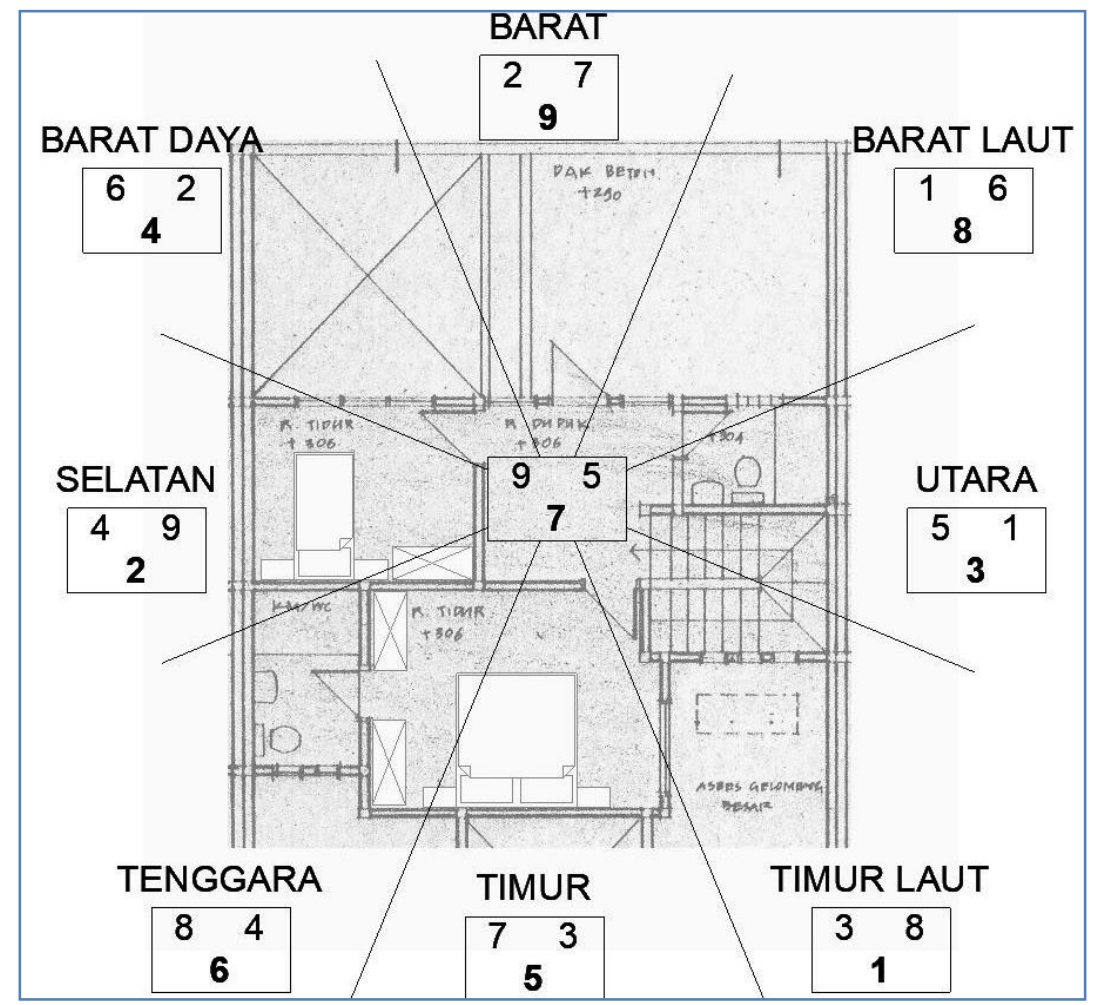

Figur 2.6. Pembagian letak ruangan lantai 2 berdasarkan Bintang Terbang

\section{$\underline{\text { Kamar Tidur Utama }}$}

Kamar tidur utama terletak pada sektor Timur yang memiliki kombinasi Bintang Gunung 7 (logam) dan Bintang Air 3 (kayu). Elemen logam pada bintang gunung mengendalikan elemen kayu pada bintang air berdasarkan siklus hubungan saling 
mengendalikan antar lima elemen. Bintang 3 merupakan bintang perampokan yang memiliki sifat asli kurang baik. Pada periode 7, kombinasi bintang 3 dan 7 dapat membawa perkembangan kekayaan ${ }^{1}$ karena bintang 7 bersifat timely. Dari hasil wawancara, pendapatan rata-rata yang diperoleh suami tidak begitu berbeda dari tahun 1996 sampai sekarang. Pada periode 8 , bintang 7 (logam) menjadi untimely dan memperbesar kemungkinan terjadinya perampokan atau terlibat dalam perkara hukum ${ }^{1}$. Dapat dilihat dari permasalahan hukum yang dialami oleh suami pada tahun 2008. Elemen Kua suami (2) dan istri (8) yang merupakan tanah juga dikendalikan oleh elemen kayu dari Bintang Air 3. Ketidakharmonisan antara elemen Kua (tanah) dengan elemen kayu pada Bintang Air menyebabkan keuangan suami dan istri kurang baik.

Kesimpulan dari analisis objek penelitian 4 adalah perubahan periode Bintang Terbang membawa pengaruh buruk pada kehidupan penghuni rumah karena berubahnya sifat timeliness (tepat waktu) pada bintang 7 (logam) di sektor pintu masuk. Pada periode 8, bintang 7 menjadi untimely yang memunculkan sifat buruknya. Kombinasi bintang gunung dan bintang air yang kurang baik pada sektor kamar tidur juga memberikan pengaruh buruk kepada penghuni rumah. Ketidakharmonisan elemen Киа suami dan elemen Kua istri bila dibandingkan dengan bintang air pada kamar tidur memungkinkan keuangan mereka menjadi kurang baik.

Objek 5. Setelah menghitung angka trigram pribadi (Kua) dari setiap penghuni Objek 5 dari tanggal lahir masing-masing didapatkan

Tabel 2.5. Elemen trigram pribadi (Kua) penghuni Objek Penelitian 5

\begin{tabular}{|c|c|c|}
\hline Anggota Keluarga & Angka Киa & Elemen Киa \\
\hline Suami & 4 & Kayu \\
\hline Istri & 8 & Tanah \\
\hline Anak 1 & 4 & Kayu \\
\hline Anak 2 & 8 & Tanah \\
\hline
\end{tabular}




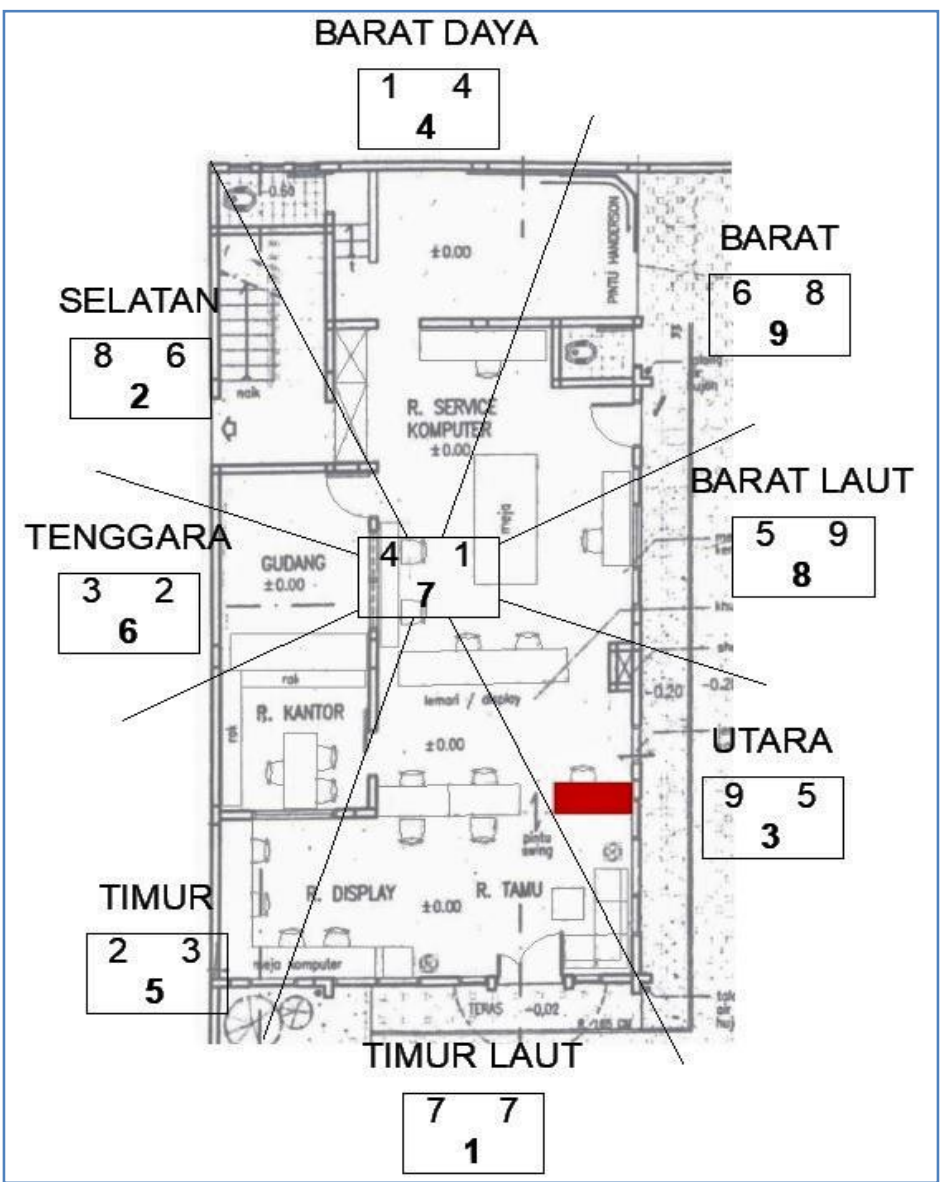

Figur 2.7. Pembagian letak ruangan lantai 1 berdasarkan Bintang Terbang

\section{$\underline{\text { Pintu Masuk Utama }}$}

Pintu masuk utama terletak pada sektor Timur Laut yang memiliki kombinasi Bintang Gunung 7 (logam) dan Bintang Air 7 (logam). Pada periode 7, kombinasi Bintang Gunung 7 dan Bintang Air 7 ini membawa keberuntungan yang besar bagi penghuni rumah, karena kedua bintang bersifat timely. Berdasarkan hasil wawancara langsung pada pemilik toko, nilai ratarata omzet penjualan toko per bulan tahun 1997 - 2003 (termasuk periode 7) mencapai Rp100.000.000,00. Nilai omzet ini berasal dari banyaknya penjualan perangkat komputer untuk instansi-instansi dan sekolah yang membeli dalam jumlah besar sehingga rata-rata keuntungan yang didapat oleh pemilik toko setiap bulan dapat mencapai Rp 30.000.000,00.

Ketika periode 7 berakhir dan memasuki periode 8, Bintang 7 kembali menjadi untimely yang menampilkan sifat buruknya. Mulai dari tahun 2005, omzet penjualan toko berkurang karena mulai bermunculan saingan usaha (toko komputer lain). Sejak tahun 2005, nilai omzet rata-rata penjualan toko per bulannya hanya mencapai Rp50.000.000,00 - Rp 70.000.000,00. Nilai ini semakin menurun ketika menginjak tahun 2011 karena selain toko komputer lain terus bermunculan, adanya toko online juga membuat harga-harga barang menjadi lebih transparan sehingga pelanggan dapat langsung membeli dari distributor besar.

\section{Meja Kasir}

Meja kasir terletak di sektor Utara yang memiliki kombinasi Bintang Gunung 9 (api) dan Bintang Air 5 (tanah). Elemen api pada biintang gunung 9 memberikan energi pada elemen tanah pada bintang air 5 sehingga Bintang Air 5 menjadi lebih kuat. Bintang 5 sejatinya merupakan bintang yang memiliki sifat buruk. Dengan tambahan energi dari bintang 9 (api), sifat buruk dari Bintang 5 ini menjadi lebih kuat. Pada periode 7, walaupun lokasi meja 
kasirnya kurang baik, tetapi lokasi pintu masuk yang berada di sektor timur laut memiliki kombinasi Bintang Gunung 7 dan Bintang Air 7 yang timely sehingga nilai omzet penjualan toko cukup tinggi.

Ketika periode 8, Bintang 7 ganda di sektor pintu masuk menjadi untimely. Perubahan sifat timeliness dari Bintang 7 (logam) ini membuat bintang 7 (logam) memiliki sifat yang kurang baik sehingga pengaruh buruk dari kombinasi bintang 9 (api) dan bintang 5 (tanah) tidak dapat diredam lagi. Dapat dilihat dari menurunnya nilai rata-rata omzet penjualan toko setelah tahun 2005 .

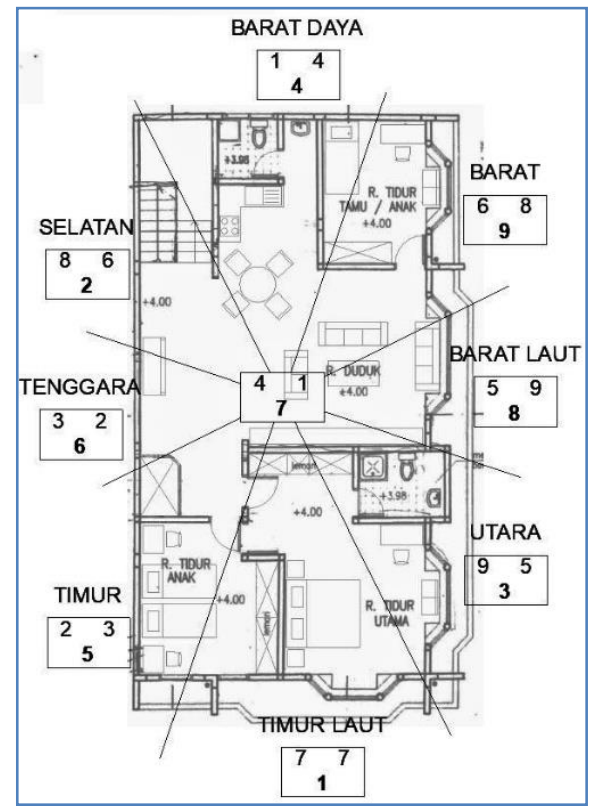

Figur 2.8. Pembagian letak ruangan lantai 2 berdasarkan Bintang Terbang

\section{$\underline{\text { Kamar Tidur Utama }}$}

Kamar tidur utama terletak pada sektor Timur Laut yang memiliki kombinasi Bintang Gunung 7 (logam) dan Bintang Air 7 (logam) dan sektor Utara yang memiliki kombinasi Bintang Gunung 9 (api) dan Bintang Air 5 (tanah). Posisi kepala pada saat tidur terletak di sektor timur laut. Pada periode 7, kombinasi Bintang Gunung 7 (logam) dan Bintang Air 7 (logam) dapat membawa keberuntungan yang besar bagi penghuni rumah, karena kedua bintang bersifat timely. Dapat dilihat dari besarnya keuntungan yang diperoleh antara tahun 1997 - 2004 (termasuk periode 7). Ketika periode 7 berakhir dan memasuki periode 8, Bintang 7 (logam) menjadi untimely yang memunculkan kembali sifat kurang baik dari bintang 7 . Menurunnya omzet penjualan toko akibat munculnya toko-toko sejenis sejak tahun 2005 (termasuk periode 8) menjadi peristiwa yang dipengaruhi sifat buruk bintang 7 .

Elemen Kua suami (4) adalah kayu dan elemen Kua istri (8) adalah tanah. Elemen kayu pada Киа suami berada dalam siklus mengendalikan dengan elemen logam pada bintang gunung 7 dan bintang air 7 sehingga keuangan dan kesehatan suami kurang baik. Ketidakharmonisan antara elemen Kua dengan elemen pada Bintang Gunung dan Bintang Air dapat memungkinkan kurang baiknya kesehatan dan keuangan penghuni rumah. Bintang 4 (kayu) juga melambangkan saluran pernapasan. Karena Bintang 4 (kayu) ini dikendalikan oleh bintang 7 (logam), maka saluran pernapasan menjadi kurang baik. Sejak tahun 2008, suami sering menderita radang tenggorokan. Pada awalnya suami tidak meminum obat apapun dan hanya beristirahat yang cukup, namun karena sudah lebih dari 4 hari tidak kunjung membaik, akhirnya beliau memutuskan untuk berobat ke dokter. Oleh dokter, beliau diberi antibiotik untuk mempercepat penyembuhan. Beberapa bulan setelah sembuh, suami lagi-lagi terserang 
radang tenggorokan. Kejadian ini terus berulang hingga sekarang. Beliau sempat disarankan oleh sepupunya untuk meminum ramuan herbal sebagai obat tradisional, namun ramuan tersebut tetap tidak dapat membuat radang tenggorokannya sembuh secara total.

Untuk istri, elemen Киа (8) yang merupakan tanah berada pada siklus saling mendukung dengan elemen logam pada bintang gunung 7 dan bintang air 7 , menyebabkan kesehatan dan keuangan istri tidak terganggu.

Kesimpulan dari analisis objek penelitian 5 adalah perubahan periode Bintang Terbang membawa pengaruh buruk pada toko dan rumah ini karena berubahnya sifat timeliness (tepat waktu) pada bintang 7 di sektor pintu masuk dan kamar tidur utama. Sektor meja kasir memang memiliki kombinasi bintang terbang yang kurang baik namun pada periode 7 masih dapat diredam karena bintang 7 bersifat timely. Pada periode 8, Bintang 7 menjadi untimely yang menyebabkan sifat kurang baiknya muncul.

\section{KESIMPULAN}

Dari hasil penelitian, dapat dilihat bahwa perubahan periode pada Feng Shui Bintang Terbang dapat mempengaruhi kehidupan penghuni rumah. Perubahan periode Feng Shui Bintang Terbang menyebabkan berubahnya sifat Timeliness dari beberapa bintang. Perubahan sifat timeliness membawa perubahan pada sifat baik atau buruknya bintang tersebut. Bintang 7 pada dasarnya memiliki sifat buruk, menjadi bintang yang baik pada Periode 7 karena adanya sifat Timely (tepat waktu). Ketika periode 7 berakhir dan memasuki periode 8, sifat timeliness dari Bintang 7 pudar dan Bintang 7 kembali menjadi bintang yang bersifat buruk.

Dari 5 rumah tinggal yang menjadi objek penelitian, 2 diantaranya merupakan rumah sekaligus toko (objek penelitian 1 dan objek penelitian 5), sementara itu 3 objek penelitian lainnya murni rumah tinggal tanpa terdapat toko di lokasi tersebut. Pada objek penelitian 1, 2, 4, dan 5, terdapat lebih dari 1 sektor yang mencakup kamar tidur utama sehingga sebenarnya ada kombinasi bintang gunung dan bintang air lain yang dapat berpengaruh pada penghuni rumah tersebut. Untuk menentukan kombinasi bintang mana yang berpengaruh, dilihat lokasi dari kepala ketika tidur di atas tempat tidur. Peletakkan kolam pada halaman rumah juga harus diperhatikan, karena kolam merupakan elemen air yang memperkuat bintang air di sektor tersebut. Apabila peletakannya pada sektor yang memilki bintang air kurang baik, maka bintang air tersebut akan aktif dan membawa pengaruh buruk pada kehidupan penghuni rumah, seperti pada objek penelitian 2 .

\section{DAFTAR PUSTAKA}

${ }^{l}$ Koh, Vincent. (2005). Basic Science of Feng Shui - Buku Pegangan bagi Praktisi. Jakarta: PT Elex Media Komputindo.

${ }^{2}$ Lip, Evelyn. (1997). What is Feng Shui?. London: Academy Group Ltd.

${ }^{3}$ Marfori, M. D. (1995). Feng Shui : Menemukan Uang, Kesehatan, dan Cinta. Jakarta: Abdi Tandur. ${ }^{4}$ Skinner, Stephen. (2002). Flying Star Feng Shui. Clarendon: Tuttle Publishing.

${ }^{5}$ Too, Lilian. (1994). Chinese Numerology in Feng Shui. Kuala Lumpur: Konsep lagenda Sdn Bhd.

${ }^{6}$ Too, Lilian. (1994). Penerapan Feng Shui Pa-Kua dan Lo-Shu (terjemahan). Jakarta: PT Elex Media Komputindo.

${ }^{7}$ Too, Lilian. (1999). Lilian Too's Flying Star Feng Shui. Kuala Lumpur: Konsep Lagenda Sdn Bhd.

${ }^{8}$ Too, Lilian. (2002). Buku Pintar Feng Shui Untuk Rumah (terjemahan). Jakarta: PT Elex Media Komputindo.

${ }^{9}$ Twicken, David. (2000). Flying Star - Feng Shui Made Easy. Lincoln: Writers Club Press. 